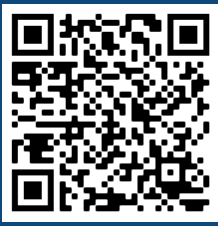

Keywords: Meliaceae Planting in the field Tropical arboreal species Received 20/04/2020 Accepted 10/07/2020

Correspondence: suaimi@gmail.com
Suelen Carpenedo Aimi ${ }^{\mathrm{la}+}$, Maristela Machado Araujo ${ }^{\mathrm{lb}}$, Luciane Almeri Tabaldilc, Thaíse da Silva Tonetto ${ }^{\text {Id }}$, Thairini Claudinio Zavistanovicz ${ }^{\text {e }}$, Álvaro Luís Pasquetti Berghetti ${ }^{\text {If }}$

\section{SHADING AS A DETERMINANT FACTOR FOR THE SURVIVAL AND GROWTH OF Cabralea canjerana IN SOUTHERN BRAZIL}

AIMI, S. C.; ARAUJO, M. M.; TABALDI, L. A.; TONETTO, T. da S.; ZAVISTANOVICZ, T. C.; BERGHETTI, Á. L. P. Shading as a determinant factor for the survival and growth of Cabralea canjerana in southern Brazil. CERNE, v. 26, n. 3, p.349-355, 2020.

\section{HIGHLIGHTS}

Light levels promoted different results in the development of plants of Cabralea canjerana.

The planting of Cabralea canjerana seedlings in full sunlight is not advised.

The electron transport rate was similar in the different shade treatments.

It is recommended that seedlings be planted under $50 \%$ shade.

\section{ABSTRACT}

Plantations with native tree species, which emphasize biodiversity conservation, may not succeed because of a lack of forestry knowledge about the native species. Cabralea canjerana is an important tree species, which is rarely present in area restoration programs because of the difficulty in establishing it in plantations. Despite this, the species is also known for its adaptation to different light conditions. Therefore, this research sought to answer: a) What is the appropriate light level for the initial establishment of Cabralea canjerana seedlings in the field? b) Does seasonality influence the morphological and physiological attributes of Cabralea canjerana plants? The treatments used were: four shade intensities $(0,18,50$ and $70 \%)$ and two seasonal periods (spring-summer and autumn-winter). Survival was evaluated at 30 and 360 days after planting, while the morphological and physiological attributes were evaluated at 180 (spring-summer) and 360 (autumn-winter) days after planting. We suggest that Cabralea canjerana be classified as a moderately shadetolerant species, considering that even in a region with four well-defined seasons, like the one in the present study, its mortality rate was high in full sun, a fact that is corroborated by the morphological and physiological parameters. The planting of Cabralea canjerana seedlings in full sunlight is not appropriate because it causes low seedling survival. It is recommended that planting be carried out under $50 \%$ shading. Seasonality influenced the morphological and physiological attributes of Cabralea canjerana plants. 


\section{INTRODUCTION}

Among the main environmental factors, light is responsible for the regulation of photosynthesis and, consequently, for plant survival, growth, and adaptation (Zervoudakis et al., 20I2). The recommend methods for tree planting depend on how much is known about seedling adaptation strategies to light availability (Quevedo-Rojas, 2018). This is because different species vary in their potentials to establish, grow, and develop relative to light availability in both the nursery and the field. Therefore, studies are necessary, especially on the light requirements of species with potential for use in afforestation, reforestation, and restoration programs.

The light energy absorbed by the chlorophyll molecules can have three different paths, which occur simultaneously, competing among themselves: a) gain by the plant through photosynthesis, b) dissipation in the form of heat, and c) chlorophyll $a$ fluorescence (Taiz et al., 20I7). Energy dissipation occurs when the reaction center of the photosystem closes, in response to some sort of stress, such as the excess of incident radiation on the leaves. The excess energy produces free radicals as a way of minimizing cell damage (Ritchie et al., 2010), but in this process, it causes lipid peroxidation, that is, the capture of electrons from the lipids present in the cell membranes (Taiz et al., 2017). According to $X u$ and Zhou (2006), photosynthesis is negatively influenced by lipid peroxidation. This, consequently, reduces plant growth and survival.

The quantification of lipid peroxidation and chlorophyll a fluorescence are techniques used to evaluate plant stress (El-Moshaty et al., 1993). At the same time, we used survival and morphological attributes as a quick way to evaluate plant quality. Studies evaluating the performance of plants at different light levels were developed for some tree species in nursery conditions (Lenhard et al., 20/3). However, studies evaluating this plasticity in the field are still needed. The plasticity of Cabralea canjerana (Vell.) Mart. (canjerana) is of fundamental importance for its cultivation and it has demonstrated a capacity to develop under various light conditions (Zimmermann et al., 2019). According to Moretti et al. (2019) the ability to adapt to different levels of canopy cover is a trait that makes species suitable for species enrichment programs in tropical forests.

Cabralea canjerana of the Meliaceae family is among the native tree species that are potentially useful for reforestation and restoration. Cabralea canjerana occurs across Bolivia, Costa Rica, Ecuador, Peru, Argentina, Paraguay, and Brazil (Tropicos, 2020) and is considered one of the most valuable species in the South of Brazil, recognized for its wood quality and great economic value (Coradin et al., 20II). In addition, this species can be used in restoration programs. Cabralea canjerana has slow to moderate growth. It occupies an intermediate position in the forest between the understory and the canopy and occurs naturally, mainly on hilltops. Furthermore, it is described in the literature as both a pioneer and climax species, as it appears in late secondary succession, but exhibits plasticity with regards to light conditions (Carvalho, 2003).

The lack of agreement regarding its successional status may cause problems with seedling survival and initial growth in the field and indicates a need for research to evaluate its behavior at different shade conditions (Carvalho, 2003; Coradin et al., 20II; Zimmermann et al., 2019). Considering that the use of native species in conservation, protection, and recovery programs requires information about the light demand of species for the success of outplanting programs, the hypothesis of this study was that shading and seasonality influence the survival and initial growth of this species. Thus, this research sought to answer: a) What is the appropriate light level for the initial establishment of Cabralea canjerana seedlings in the field? b) Does seasonality influence Cabralea canjerana performance?

\section{MATERIAL AND METHODS}

The study was conducted in the Forest Nursery

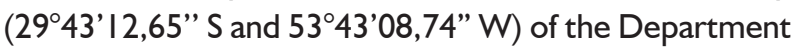
of Forest Sciences, at the Federal University of Santa Maria (UFSM), in Southern Brazil. According to the classification of Köppen, the climate in the region is subtropical ( $\mathrm{Cfa}$ ), characterized by average temperature between -3 and $18{ }^{\circ} \mathrm{C}$ in the coldest month, and above $22{ }^{\circ} \mathrm{C}$ in the hottest month, with average annual rainfall ranging from 1600 to $1900 \mathrm{~mm}$ (Alvares et al., 20I3). Figure I shows the monthly precipitation averages and the maximum, minimum and average temperatures recorded in the municipality of Santa Maria during the experiment period (August 2012 to August 2013). Four well-defined seasons occur in the region. The coldest months in the year of study occurred between May and August, whereas the hottest months occurred between November and February.

In the planting area, soil samples were collected and then sent to the Soil Analysis Laboratory (UFSM). This analysis indicated a pH of 4.9 to 6.0 , corresponding to an acid soil, low organic matter content (OM) (I.3 to $2.0 \%$ ), very low to low phosphorus content (3.4 to 
$\left.4.2 \mathrm{mg} \cdot \mathrm{dm}^{-3}\right)$, high potassium $\left(60\right.$ to $\left.82 \mathrm{mg} \cdot \mathrm{dm}^{-3}\right)$, high magnesium ( 1.3 to $\left.2.4 \mathrm{cmol}_{\mathrm{c}} \cdot \mathrm{dm}^{-3}\right)$, medium to high calcium $\left(3.5\right.$ to $\left.6.9 \mathrm{cmol} \cdot \mathrm{dm}^{-3}\right)$, SMP index ranging from 5.4 to 6.4 , and mean $\mathrm{pH} 7$ (CTC) (I 2.4 to $13.2 \mathrm{cmol}_{\mathrm{c}}$. $\left.\mathrm{dm}^{-3}\right)$ (SBCS/CQFS, 2004).

Soil acidity correction was performed according to the SMP index, with incorporation of dolomitic limestone to the soil in total area (PRNT of $75.1 \%$ ) one month before the planting (July 20I2). For outplanting, pits measuring $30 \mathrm{~cm}$ in diameter $\times 35 \mathrm{~cm}$ in depth $(0.02$ $\mathrm{m}^{3}$ or $\cong 25 \mathrm{~L}$ ), with a space of $\mathrm{I} \times \mathrm{I} \mathrm{m}$ between plants were opened with the aid of a tractor and a drill bit. The Cabralea canjerana seedlings used in the planting had an average of $14.6 \mathrm{~cm}$ in height and $5.6 \mathrm{~mm}$ in diameter.

The irrigation of the seedlings was performed every three days in the first week with two liters of water per plant and, subsequently, once a week in the absence of precipitation (Figure I). A mulched vegetation cover (approximately $35 \mathrm{~cm}$ diameter, 5 $\mathrm{cm}$ height) was placed and maintained around the seedlings. Cover fertilizations were carried out at 30 and 180 days after planting, with $100 \mathrm{~g}$ of NPK 5-2020 (urea, phosphorus oxide and potassium chloride). Ant control was carried out using granulated formicide and the weed competition was controlled with manual weeding around the seedlings (crowning) and chemical weeding in the rest of the area.

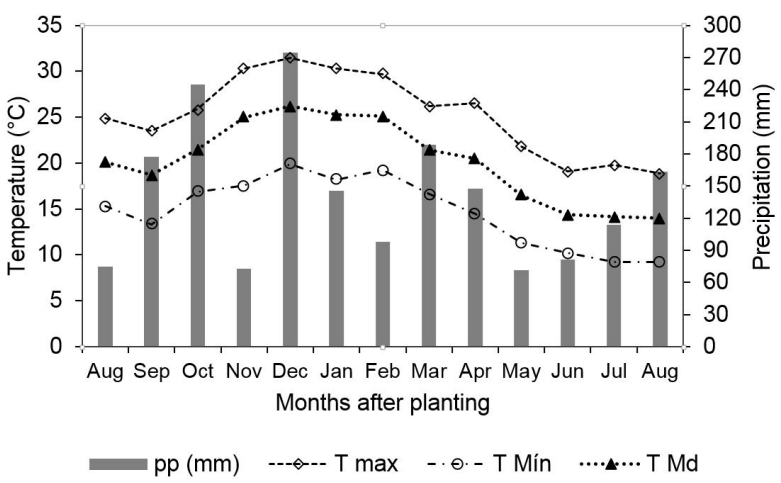

FIGURE I Monthly climatic data for Santa Maria (RS) over the course of our year-long experiment with Cabralea canjerana seedlings. T: temperature (Md: average; Max: maximum; Min: minimum); pp: precipitation. Source: Climatological Station of Santa Maria, Federal University of Santa Maria.

A randomized block design was used in a $4 \times$ 2 factorial scheme (four shading intensities and two seasonal periods of the year), for the morphological and physiological attributes, in five blocks with four seedlings per replicate, totaling 80 plants, which were evaluated during the experiment. The shading intensities were: $0 \%$ (full sunlight), $18 \%, 50 \%$ and $70 \%$ shade, respectively, and were obtained through the use of shading screens arranged under arches, providing a height of about 3 meters. As for the time factor, two seasonal periods of the year were considered, spring-summer and autumn-winter.

The survival was visually assessed at 30 and 360 days after planting (d.a.p). The morphological and physiological attributes were verified at 180 d.a.p between spring and summer (S-S) and at 360 d.a.p between autumn and winter $(A-W)$. The height $(H)$ was measured with a ruler $(\mathrm{cm})$ and the stem diameter (SD) with a digital caliper $(\mathrm{mm})$, with all the plants in the plot being evaluated. The calculation of the increase in height (Inc $\mathrm{H}$ ) and increment in stem diameter (Inc. SD) was performed by subtracting the values measured at 180 d.a.p from those measured at time 0 (planting time) and from 360 d.a.p in relation to 180 d.a.p.

Chlorophyll $a$ fluorescence was evaluated in three plants per treatment in the fourth expanded leaf, which was previously adapted to the dark with aluminum foil for $30 \mathrm{~min}$. Then, the analyses were carried out using a JUNIOR-PAM portable light-modulating fluorometer (Walz, Germany), obtaining the electron transport rate (ETR) and the maximum quantum yield of photosystem II $\left(F / F_{m}\right)$, with the variable fluorescence being represented by: $F_{v}=F_{m}-F_{\text {。 }}$ $\left(F_{m}\right.$ : maximum fluorescence; $F_{o}$ : initial fluorescence).

The physiological attributes related to the photosynthetic pigments and lipid peroxidation were determined at the Plant Biotechnology Laboratory (UFSM). To this end, the fourth expanded leaf was collected from three plants per treatment, totaling 12 plants, which were frozen in liquid $\mathrm{N}_{2}$ and stored in ultrafreezer at $-80^{\circ} \mathrm{C}$.

The photosynthetic pigments were determined following the methodology of Hiscox and Israeslstam (1979), and estimated by the Lichtenthaler formula (Lichtenthaler, 1987). Fresh leaf samples (0.05 g) were incubated at $65^{\circ} \mathrm{C}$ with dimethylsulfoxide (DMSO) for two hours. The absorbances of the solution were measured in a spectrophotometer (Celm E-205 D) (Bel Engenneering, Italy) at 663, 645 and $470 \mathrm{~nm}$ for chlorophyll $a$, chlorophyll $b$ and carotenoids, respectively. Peroxidation of membrane lipids was estimated following the method of El-Moshaty et al. (1993).

Data were checked for assumptions of normality and homogeneity by the Shapiro-Wilk and Bartlett tests, respectively, using the software Action (Equipe Estatcamp, 2014). They were subsequently submitted to analysis of variance and, when differences between treatments were found, the means were compared by the $t$-test and the Scott-Knott's test $(p<0.05)$. The statistical software Sisvar (Ferreira, 2014) was used to analyze the data. 


\section{RESULTS}

The survival of Cabralea canjerana seedlings at 30 days after planting was $100 \%$ in the $18 \%, 50 \%$, and $70 \%$ shading treatments, whereas survival was $75 \%$ in the full sunlight ( $0 \%$ shading) treatment (Table I). The same result was observed at 360 days, when $85 \%$ of seedlings survived under $18 \%$ shading, which did not significantly differ from seedling survival at $50 \%$ and $70 \%$ shading, respectively.

TABLE I Survival of Cabralea canjerana seedlings, at 30 and 360 days after planting in the field, at different levels of shading.

\begin{tabular}{ccc}
\hline Levels of shading & \multicolumn{2}{c}{ Survival (\%) } \\
\cline { 2 - 3 }$(\%)$ & 30 days after planting & 360 days after planting \\
\hline 0 & $75 \mathrm{~b}^{*}$ & $30 \mathrm{~b}$ \\
18 & $100 \mathrm{a}$ & $85 \mathrm{a}$ \\
50 & $100 \mathrm{a}$ & $80 \mathrm{a}$ \\
70 & $100 \mathrm{a}$ & $65 \mathrm{a}$ \\
\hline
\end{tabular}

*Averages followed by different letters in the column differ from each other by the Scott-Knott Test $(p<0.05)$.

There was no significant interaction (shading $x$ seasonal periods) for the morphological variables height, increment in height, stem diameter, and increment in stem diameter or for the physiological variables maximum quantum yield of photosystem II and rate of electron transport in Cabralea canjerana seedlings. A significant effect $(p<0.05)$ was observed only for the isolated factors (Table 2 and 3). Average seedling height was higher under $50 \%$ and $70 \%$ shading $(34.83$ and $33.8 \mathrm{Icm}$, respectively) than under $18 \%$ shading $(28.48 \mathrm{~cm})$ or full sun $(0 \%$ shading, $24.07 \mathrm{~cm}$ ) (Table 2$)$. In addition, there was a significant difference in seedling height between the seasonal periods, with the highest average observed in the autumn-winter season (A-W) (Table 2). Furthermore, the increase in seedling height $(\mathrm{Inc} H)$ was significantly greater in the $18 \%, 50 \%$, and $70 \%$ shade treatments than in the $0 \%$ shade treatment (Table 2). The stem diameter (SD) means and increment in SD (Inc SD) were significantly higher in the A-W period (Table 2). Shading, however, had no impact on either SD or Inc SD (Table 2).

The quantum yield $\left(F_{J} / F_{m}\right)$ was significantly higher under $70 \%$ shading than at other levels of shading and significantly higher in the S-S season than in the A-W season (Table 2). The electron transport rate (ETR) was similar across the different shading treatments, but it had significantly greater efficiency in the S-S period than in the A-W (Table 2).

The treatments (shade $\times$ season) presented a significant interaction $(\mathrm{p}<0.05)$ for chlorophyll $a$, chlorophyll $b$, carotenoids, and lipid peroxidation. For both seasons, chlorophyll $a$ concentration were higher under $50 \%$ and $70 \%$ shading than under either $18 \%$ or $0 \%$ shading (Table 3). In the S-S period, chlorophyll $b$ was lowest at full sun, which is similar to the results
TABLE 2 Height $(H)$, increase in height (Inc $H$ ), stem diameter (SD), increment in stem diameter (Inc $\mathrm{SD})$, maximum quantum yield of photosystem II $\left(\mathrm{F}_{/} / \mathrm{F}_{\mathrm{m}}\right)$ and electron transport rate (ETR) averages of Cabralea canjerana seedlings in different levels of shading, in two seasonal periods in the field, springsummer (S-S) and autumn-winter (A-W).

\begin{tabular}{|c|c|c|c|c|c|c|}
\hline $\begin{array}{c}\text { Shading } \\
\text { Intensities } \\
\text { (\%) }\end{array}$ & $\begin{array}{c}\mathrm{H} \\
(\mathrm{cm})\end{array}$ & $\begin{array}{l}\text { Inc H } \\
(\mathrm{cm})\end{array}$ & $\begin{array}{l}\text { SD } \\
(\mathrm{mm})\end{array}$ & $\begin{array}{c}\text { Inc SD } \\
(\mathrm{mm})\end{array}$ & $\mathrm{F} / \mathrm{F}_{\mathrm{m}}$ & $\begin{array}{c}\text { ETR } \\
\mu \mathrm{mol} \cdot \mathrm{m}^{-2} \cdot \mathrm{s}^{-1}\end{array}$ \\
\hline 0 & 24.07 b* & $3.38 \mathrm{~b}$ & $10.67 \mathrm{a}$ & $3.99 a$ & $0.53 \mathrm{~b}$ & $18.82 \mathrm{a}$ \\
\hline 18 & $28.48 \mathrm{~b}$ & $13.79 \mathrm{a}$ & $12.84 \mathrm{a}$ & $5.48 \mathrm{a}$ & $0.45 \mathrm{~b}$ & $14.13 \mathrm{a}$ \\
\hline 50 & $34.83 \mathrm{a}$ & $20.45 \mathrm{a}$ & $13.67 \mathrm{a}$ & $6.31 \mathrm{a}$ & $0.47 \mathrm{~b}$ & $15.72 \mathrm{a}$ \\
\hline 70 & $33.81 \mathrm{a}$ & $19.54 \mathrm{a}$ & $12.37 \mathrm{a}$ & $5.75 \mathrm{a}$ & $0.59 \mathrm{a}$ & $15.28 \mathrm{a}$ \\
\hline $\begin{array}{c}\text { Seasonal } \\
\text { Period }\end{array}$ & $\begin{array}{c}\mathrm{H} \\
(\mathrm{cm})\end{array}$ & $\begin{array}{l}\text { Inc H } \\
(\mathrm{cm})\end{array}$ & $\begin{array}{c}\mathrm{SD} \\
(\mathrm{mm})\end{array}$ & $\begin{array}{c}\text { Inc SD } \\
(\mathrm{mm})\end{array}$ & $\mathrm{Fv} \cdot \mathrm{Fm}^{-1}$ & $\begin{array}{c}\text { ETR } \\
\mu \mathrm{mol} \cdot \mathrm{m}^{-2} \cdot \mathrm{s}^{-1}\end{array}$ \\
\hline S-S & $24.48 \mathrm{~b}$ & $9.91 \mathrm{~b}$ & $8.59 \mathrm{~b}$ & $3.18 \mathrm{~b}$ & $0.57 \mathrm{a}$ & $19.30 \mathrm{a}$ \\
\hline A-W & $36.12 \mathrm{a}$ & $18.66 \mathrm{a}$ & $16.18 \mathrm{a}$ & $7.60 \mathrm{a}$ & $0.45 \mathrm{~b}$ & $12.68 \mathrm{~b}$ \\
\hline $\begin{array}{l}\text { CV } \\
(\%)\end{array}$ & 7.2 & 35.4 & 9.9 & 37.9 & 20.13 & 41.71 \\
\hline
\end{tabular}

*Averages followed by different letters in the column differ from each other by the Scott-Knott test (shade levels) and $t$-test (periods) $(\mathrm{p}<0.05)$ and CV: Coefficient of variation.

obtained for chlorophyll $a$ during this season (Table 3 ). The highest carotenoid content was found in the $0 \%$ and $70 \%$ shading treatments in the S-S season (Table 3).

The highest lipid peroxidation occurred in the A-W seasonal period, mainly in the high-shade treatments (i.e., $50 \%$ and $70 \%$ shade, Table 3). In S-S we observed the opposite response, with higher lipid peroxidation in the environments with higher light incidence (Table 3). In the A-W season, lipid peroxidation was lowest in the low $(I 8 \%)$ and no $(0 \%)$ shading treatments (Table 3$)$.

\section{DISCUSSION}

The initial survival (30 days) of Cabralea canjerana plants was high if we consider that this is a native species, but over time, they were shown to be better adapted to moderate shading (Table I). This species grows slowly, as

TABLE 3 Means of chlorophyll $a$, chlorophyll $b$, carotenoids and lipid peroxidation of Cabralea canjerana seedlings under different shading intensities $(0,18$, 50 and $70 \%$ ), two seasonal periods of the year, spring-summer (SS) and autumn-winter (AW).

\begin{tabular}{|c|c|c|c|c|c|c|c|c|}
\hline \multirow[t]{3}{*}{$\begin{array}{c}\text { Shading } \\
\text { Intensities } \\
(\%) \\
\end{array}$} & \multirow{2}{*}{\multicolumn{2}{|c|}{$\begin{array}{l}\text { Chlorophyll a } \\
\text { (mg.g' } g^{-1} \text { FM) }\end{array}$}} & \multicolumn{2}{|c|}{$\begin{array}{l}\text { Chlorophyll b } \\
\left(\mathrm{mg} \cdot \mathrm{g}^{-1} \mathrm{FM}\right)\end{array}$} & \multicolumn{2}{|c|}{$\begin{array}{l}\text { Carotenoids } \\
\left(\mathrm{mg} \cdot \mathrm{g}^{-1} \mathrm{FM}\right)\end{array}$} & \multicolumn{2}{|c|}{$\begin{array}{l}\text { Lipid peroxidation } \\
\text { (nmol de MDA. } \\
g^{-1} \text { FM) }\end{array}$} \\
\hline & & & \multicolumn{4}{|c|}{ Seasonal period } & & \\
\hline & S-S & A-W & S-S & A-W & S-S & A-W & S-S & A-W \\
\hline 0 & $0.66 \mathrm{Bd}^{*}$ & $0.74 \mathrm{Ac}$ & $0.16 \mathrm{Bb}$ & $0.2 \mathrm{IAc}$ & $4.63 \mathrm{Aa}$ & $0.34 \mathrm{Bc}$ & $0.98 \mathrm{Ab}$ & $1.64 \mathrm{Ba}$ \\
\hline 18 & $0.73 A c$ & $0.20 \mathrm{Ac}$ & $0.19 \mathrm{Ab}$ & $0.18 \mathrm{Ac}$ & $3.93 \mathrm{Ab}$ & $0.24 \mathrm{Bb}$ & $0.76 \mathrm{Ab}$ & $1.62 \mathrm{Ba}$ \\
\hline 50 & $1.80 \mathrm{Aa}$ & $1.35 \mathrm{Ba}$ & $0.43 \mathrm{Aa}$ & $0.43 \mathrm{Aa}$ & $3.11 \mathrm{Ac}$ & $0.46 \mathrm{Ba}$ & $0.59 \mathrm{Aa}$ & $2.45 \mathrm{BC}$ \\
\hline 70 & $0.82 \mathrm{Bb}$ & $1.07 \mathrm{Ab}$ & $0.23 \mathrm{Ab}$ & $0.25 \mathrm{Ab}$ & $4.35 \mathrm{Aa}$ & $0.22 \mathrm{Bd}$ & $0.45 \mathrm{Aa}$ & $2.09 \mathrm{Bb}$ \\
\hline CV (\%) & \multicolumn{2}{|c|}{3.65} & \multicolumn{2}{|c|}{7.83} & \multicolumn{2}{|c|}{2.18} & \multicolumn{2}{|c|}{6.74} \\
\hline
\end{tabular}

* Uppercase letters denote significant differences between shading treatments (Scott-Knott's test), whereas lowercase letters denote differences between seasons ( $t$-test, $p<0.05)$ and CV: Coefficient of variation and FM: fresh matter. Spring and summer (S-S), autumn and winter (A-W). 
was observed across all of the light conditions evaluated, presumably in response to its low maximum quantum yield (Table 2). In spite of this, we highlight that at higher shade levels, the increment in height increases, possibly as a plant strategy to maximize the absorption of light radiation.

In addition, although the stem diameter (SD) is a variable that may represent post-planting performance, we have shown that the species invested higher carbon allocation for height growth. Accordingly, there were no differences in SD among the shade treatments evaluated.

The morphological and physiological attributes are highly interconnected and, therefore, we know that they concomitantly influence plant performance. The photosynthetic pigments were produced in accordance with light availability and characteristics of the plant. During the longest photoperiod (i.e., S-S), the contents of chlorophyll $a$ and $b$ increased to capture light energy, while photoprotective carotenoids increased in full sun and $70 \%$ shading (Table 3 ).

This is because chlorophyll $a$ acts in both the antenna system and the reaction center, but its production depends on the need to compensate for reductions in the photosynthetic process under lower light intensity (Taiz et al., 2017; Mathur et al., 2018). Thus, as for chlorophyll $a$, the increase of chlorophyll $b$ is an important feature in shaded environments, since a higher proportion of chlorophyll $b$ makes it possible to capture photons of other wavelengths, which is made possible by changes in leaf composition as an adaptive form to the condition of the medium (Taiz et al., 20I7). According to Lichtenthaler and Babani (2007), sun leaves respond to high irradiance and reduce the chlorophyll content in the antenna complex. The shade leaves generally have higher chlorophyll concentrations than sun leaves (Larcher, 2004), as the concentration of chlorophyll per chloroplast increases (Lambers et al., 2008). Thus, the greater accumulation of total chlorophyll in the shaded leaves may have favored Cabralea canjerana growth under shading.

Having the highest levels of chlorophyll in leaves from shaded environments is a plant strategy to adapt to lower levels of light availability (Table 3 ). Because, when plants grow in environments with low irradiance, they tend to increase the amount of chlorophylls as a compensation mechanism to the condition of lower energy in the photosynthetic apparatus (Dutra et al., 2012), as observed in the plants of Cabralea canjerana.

Carotenoids, in addition to the photoprotective action, are responsible for increasing light uptake at wavelengths different from those captured by the chlorophylls (Taiz et al., 2017; Mathur et al., 2018). For canjerana, production of carotenoids for protection was likely required when the plants were exposed to high light radiation, whereas Cabralea canjerana likely produces carotenoids to capture alternative light wavelengths in shaded environments; this may explain why carotenoid concentrations were observed to be highest at both high $(70 \%)$ and no $(0 \%)$ shading and lowest at intermediate ( $18 \%$ and $50 \%$ ) shading (Table 3).

However, in full sun, the carotenoids were not able to protect the seedlings from the excess of irradiance, as evidenced by the low survival rate of the species at 360 days (30\%) and by the lower growth in height (Table I and 2). This indicates that the planting of Cabralea canjerana seedlings in full sun conditions is disadvantageous, as it compromises their morphophysiological attributes and causes greater lipid peroxidation, especially under conditions of greater photoperiod and temperature (S-S) (Table 3).

The maximum quantum yield of photosystem II $\left(F / F_{m}\right)$ and the electron transport rate were higher in the seasonal period S-S, when the longest photoperiod occurs, as this is the period of greatest plant growth in the region. In the A-W period, the $F_{\sqrt{ }} / F_{m}$ values $(0.45)$ indicated stress caused by low temperatures (Figure I).

Higher $F / F_{m}$ ratios indicate that light is being directed towards photosynthesis (Baker, 2008). These responses may be region and species-specific because, according to Araújo and Deminicis (2009) and Ritchie et al. (20I0), ideal values show $F / F_{m}$ ratio between 0.7 and 0.8 . The $F / F_{m}$ results found in this study at the $S-S$ station are in agreement with those described in the literature for native tree species in southern Brazil which have been reported to range from 0.55 to 0.7 (Turchetto et al., 2016; Aimi et al., 2017; Berghetti et al., 2020). The ETR values were lower than $300 \mu \mathrm{mol}$ (electrons) $\mathrm{m}^{-2} \mathrm{~s}^{-1}$ (Ritchie et al., 2010), but with low values $(S-S=19.3$ $\mu \mathrm{mol} \mathrm{m}^{-2} \mathrm{~s}^{-1}$ ) when compared to the established upper limit, which suggests the electrons are being transported more slowly in the photosystem.

During S-S, lipid peroxidation was higher in full sun $\left(0.98 \mathrm{nmol}\right.$ of MDA $\left.\mathrm{g}^{-1} \mathrm{FM}\right)$ and under low (18\%) shading $\left(0.76 \mathrm{nmol}\right.$ of MDA $\left.\mathrm{g}^{-1} \mathrm{FM}\right)$, which indicates that in seasons with greater photoperiod and/or temperature (Figure I), light radiation caused damage to the plant cell membrane. When plants are exposed to high irradiance, the balance between the production of oxygen reactive species and the defense mechanisms of the plant can be altered, resulting in damage to the cells (Taiz et al., 2017). During the period A-W, the values were significantly higher in all shade conditions, which is possibly associated with the deciduous characteristic of 
this species, with loss of leaves in the period of lower temperature (Figure I). Thus, an excess or a deficiency of light energy, as well as low temperatures, can lead to the production of reactive species, causing damage to the photosynthetic apparatus.

In the A-W season, short days and low ambient temperatures have a negative influence on most of the physiological attributes of Cabralea canjerana plants, which can alter processes such as photosynthesis, thus reducing plant growth and development.

When light intensities are truly low for the species, stress occurs on plants, as irradiance limits photosynthesis and, consequently, net carbon gain and plant growth. However, high light intensity can also cause stress and photoinhibition. Both situations are enhanced when, at the same time, other restrictive environmental factors, such as low or high temperature, occur (Lambers et al., 2008).

Cabralea canjerana is classified from pioneer (Carvalho, 2003) to shade-tolerant species (Ortega, 1995). This plasticity (and the accompanying multiple successional-stage classifications for this species) is possibly associated with its wide geographic distribution, across which interactions with various climatic factors can provide diverse phenotypes. However, we propose that Cabralea canjerana be classified as a moderately shadetolerant species, considering that even in a region where the four seasons are well defined, as the one in the present study, there was a high mortality in full sun (Table I), a fact that is corroborated by the poor plant performance under full sun according to the morphological and physiological parameters we measured (Table 2 and 3). Under $50 \%$ shading, the species performed better, also in the months of greater photoperiod and temperature, and it should be implanted in the enrichment of areas.

\section{CONCLUSIONS}

The planting of Cabralea canjerana seedlings in full sunlight is not advised, as full sunlight causes low seedling survival. It is recommended that the planting be carried out under $50 \%$ shading, as $50 \%$ shading increases seedling survival and the morphological and physiological quality of the plants.

Seasonality influenced the morphological and physiological attributes of Cabralea canjerana plants.

\section{ACKNOWLEDGEMENTS}

Thanks to the Higher Education Personnel Improvement Coordination (CAPES) for granting scholarship to the first author and to the National Scientific and Technological Development Council (CNPq) for the "Scholarship of Productivity in Research" provided to the second author.

\section{REFERENCES}

AIMI, S. C.; ARAUJO, M. A.; TONETTO, T. S.; TABALDI, L. A.; WITT, C. S.; GOMES, J. F.; GOMEZ, G. D. Shading as a conditioning factor to forest species planting: a study with Apuleia leiocarpa. Bosque, v. 38, n. 2, p. 37I-379, 2017.

ALVARES, C. A.; STAPE, J. L.; SENTELHAS, P. C.; GONÇALVES, J. L. M.; SPAROVEK, G. Köppen's climate 353 classification map for Brazil. Meteorologische Zeitschrift, v. 22, n. 6 , p. $711-728,2013$.

ARAÚJO, S. A. C.; DEMINICIS, B. B. Fotoinibição da fotossíntese. Revista Brasileira de Biociências, v. 7, n. 4, p. 463-472, 2012.

BAKER, B. Chlorophyll fluorescence: a probe of photosynthesis in vivo. Annual Review of Plant Biology, v. 59, p. 89I I3, 2008.

BERGHETTI, A. L. P. ; ARAUJO, M. M.; TABALDI, L.; TURCHETTO, F; AIMI, S. C.; RORATO, D.; MARCHEZAN, C.; GRIEBELER, A. M.; BARBOSA, F. M.; BRUNETTO, G. Morphological, physiological and biochemical traits of Cordia trichotoma under phosphorous application and a water-retaining polymer. Journal of Forestry Research, v. 3I, n. 3, p. I-I I, 2020.

CORADIN, L.; SIMINSKI, A.; REIS, A. Espécies nativas da flora brasileira de valor econômico atual ou potencial: plantas para o futuro Região Sul. Brasília: MMA, 20I I. 934 p.

CARVALHO, P. E. R. Espécies arbóreas brasileiras. Colombo: EMBRAPA Florestas. 2003. 1039 p.

DUTRA, T. R.; MASSAD, M. D.; SANTA, R.C. Parâmetros fisiológicos de mudas de copaíba sob diferentes substratos e condições de sombreamento. Ciência Rural, v. 42, n. 7, p. $|2| 2-|2| 8,20 \mid 2$.

EL-MOSHATY, F. I. B.; PIKE, S. M.; NOVACKY, A. J.; SEHGAL, O. P. Lipid peroxidation and superoxide production in cowpea (Vigna unguiculata) leaves infected with tobacco ringspot virus or southern bean mosaic virus. Physiological and Molecular Plant Pathology, v. 43, p. 109-I 19, 1993.

EQUIPE ESTATCAMP. Software Action. Estatcamp Consultoria em estatística e qualidade, São Carlos, São Paulo, Brasil. 2014.

FERREIRA, D. F. Sisvar: a guide for its bootstrap procedures in multiple comparisons. Ciência e Agrotecnologia, v. 38, n. 2, p. 109-II2, 2014.

HISCOX, J. D.; ISRAELSTAM, G. F. A method for the extraction of chlorophyll from leaf tissue without maceration. Canadian Journal of Botany, v. 57, p. I I32- I334, 1979.

LAMBERS, H.; CHAPIN III, F. S.; PONS, T. L. Plant physiological ecology. Springer Science \& Business Media, 2008. 605 p.

LARCHER, W. Ecofisiologia vegetal. Rima, 2004. 53 I p. 
LENHARD, N. R.; PAIVA, N. V. B.; SCALON, S. D. P. Q.; ALVARENGA, A. A. Crescimento de mudas de pauferro sob diferentes níveis de sombreamento. Pesquisa Agropecuária Tropical, v. 43, n. 2, p. 178-186, 2013.

LICHTENTHALER, H. K. Chlorophylls and carotenoids: pigments of photosynthetic biomembranes. Methods in Enzymology, v. I48, p. 350-382, 1987.

LICHTENTHALER, H. K.; BABANI, F. Differences in pigment composition, photosynthetic rates and chlorophyll fluorescence images of sun and shade leaves of four tree species. Plant Physiology and Biochemistry, v. 45, n. 8, p. 577-588, 2007.

MATHUR, S.; JAIN, L.; JAJOO, A. Photosynthetic efficiency in sun and shade plants. Photosynthetica, v. 56, n. I, p. 354$365,2018$.

MORETTI, A.; OLGUIN, F; PINAZO, Y.; MARTÍN, A.; GRACIANO, C. Water and light stresses drive acclimation during the establishment of a timber tree under different intensities of rainforest canopy coverage. Cerne, v. 25, n. I, p. 93-104, 2019.

ORTEGA, L. S. de. Temperamento de luz de los arboles del alto Paraná y potencial de regeneración forestal. Ka'a guy, Assunción, v. II, p. 16-20, 1995.

QUEVEDO-ROJAS, A.; GARCÍA-NÚÑEZ, C.; MJEREZ-RICO, M.; R JAIMEZ, R.; T SCHWARZKOPF, T. Leaf acclimation strategies to contrasting light conditions in saplings of different shade tolerance in a tropical cloud forest. Functional Plant Biology, v. 45, n. 9, p. 968-982, 2018.

RITCHIE, G. A.; LANDIS, T. D.; DUMROESE, R. K. Assessing plant quality. Seedling Processing, Storage, and Outplanting. Department of Agriculture Forest Service. 2010. 200 p.
SOCIEDADE BRASILEIRA DE CIÊNCIA DO SOLO, BR/ COMISSÃO DE QUÍMICA E FERTILIDADE DO SOLO, BR (SBCS/CQFS). Manual de adubação e de calagem para os estados do RS e SC. Sociedade Brasileira de Ciência do Solo - Núcleo Regional Sul, 2004. 394 p.

TAIZ, L.; ZEIGER, E.; MOLLER, I.; MURPHY, A. Fisiologia e desenvolvimento vegetal. Artmed, $2017.888 \mathrm{p}$.

TROPICOS, Missouri botanical garden. 2020. Disponível em: < http://www.tropicos.org/Name/20400624. Acesso em: 5 março 2020.

TURCHETTO, F; ARAUJO, M. M.; TABALDI, L. A.; GRIEBELER, A. M.; RORATO, D. G.; AIMI, S. C.; BERGHETTI, Á. L. P.; GOMES, D. R. Can transplantation of forest seedlings be a strategy to enrich seedling production in plant nurseries? Forest Ecology and Management, v. 375, n. I, p. 96-104, 2016.

XU, Z. Z.; ZHOU, G. S. Combined effects of water stress and high temperature on photosynthesis, nitrogen metabolism and lipid peroxidation of a perennial grass Leymus chinensis. Planta, v. 224, n. 5, p. 1080-1090, 2006.

ZERVOUDAKIS, G.; SALAHAS, G.; KASPIRIS, G.; KONSTANTOPOULOU, E. Influence of light intensity on growth and physiological characteristics of common sage (Salvia officinalis L.). Brazilian Archives of Biology and Technology, v. 55, n. I, p. 89-95, 2012.

ZIMMERMANN, A. P. L.; FLEIG, F. D.; TABALDI, L. A.; AIMI, S. C. Morphological and physiological plasticity of saplings of Cabralea canjerana (Vell.) Mart. in different light conditions. Revista Árvore, v. 43, n. I, e430103, 2019. 